Jules Polonetsky and Omer Tene:

\title{
The Ethics of Student Privacy: Building Trust for Ed Tech
}

\begin{abstract}
:
This article analyzes the opportunities and risks of data driven education technologies (ed tech). It discusses the deployment of data technologies by education institutions to enhance student performance, evaluate teachers, improve education techniques, customize programs, devise financial assistance plans, and better leverage scarce resources to assess and optimize education results. Critics fear ed tech could introduce new risks of privacy infringements, narrowcasting and discrimination, fueling the stratification of society by channeling "winners" to a "Harvard track" and "losers" to a "bluer collar" track; and overly limit the right to fail, struggle and learn through experimentation. The article argues that together with teachers, parents and students, schools and vendors must establish a trust framework to facilitate the adoption of data driven ed tech. Enhanced transparency around institutions' data use philosophy and ethical guidelines, and novel methods of data "featurization," will achieve far more than formalistic notices and contractual legalese.
\end{abstract}

\section{Agenda:}

Changes in education

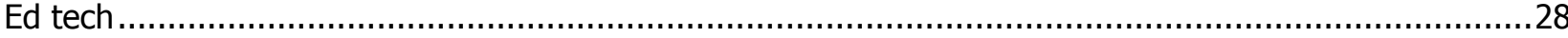

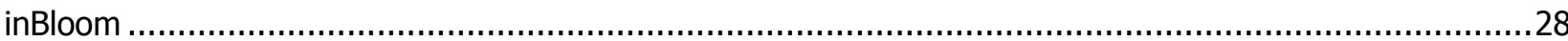

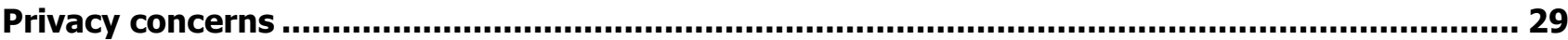

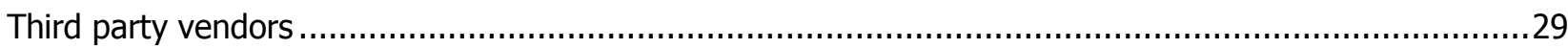

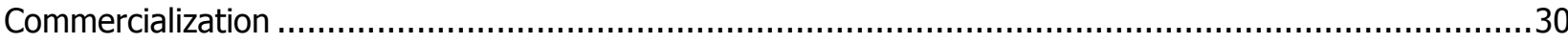

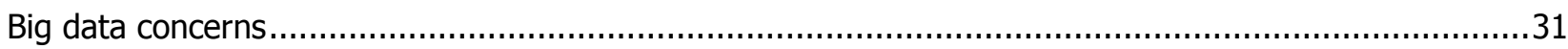

A solution toolkit............................................................................................................. 31

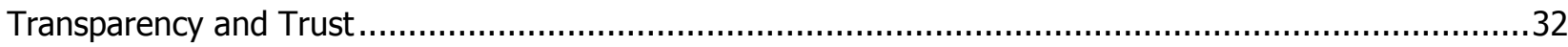

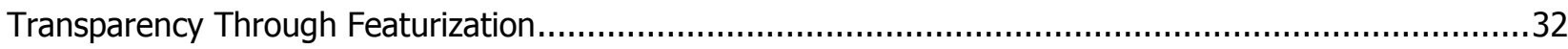

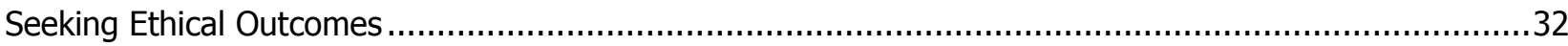

\section{Authors:}

Jules Polonetsky

- Co-chair and Executive Director, Future of Privacy Forum, 919 18th Street NW, Suite 901, Washington, DC 20006

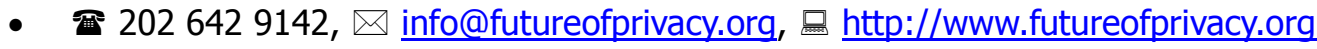

Omer Tene

- VP of Research and Education, IAPP, 75 Rochester Avenue, Portsmouth, NH

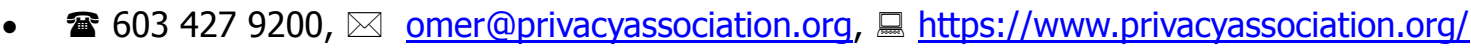


- Relevant publications:

- Jules Polonetsky \& Omer Tene, Privacy and Big Data: Making Ends Meet, 66 Stan. L. Rev. Online 25 (2013).

- Omer Tene \& Jules Polonetsky, Judged by the Tin Man: Empowering Individuals in an Age of Big Data, 11 J. Telecom. \& High Tech. L. 351 (2013).

- Omer Tene \& Jules Polonetsky, Big Data for All: Privacy and User Control in the Age of Analytics, $11 \mathrm{Nw}$ J. Tech \& IP 239 (2013).

- Omer Tene \& Jules Polonetsky, Privacy in the Age of Big Data: A Time for Big Decisions, 64 Stan. L. Rev. Online 63 (2012).

- Omer Tene \& Jules Polonetsky, To Track or 'Do Not Track': Advancing Transparency and Individual Control in Online Behavioral Advertising, 13 Minn. J. L. Sci. \& Tech. 281 (2012). 
The rapid rise, and startling demise, of inBloom, the high flying, richly financed, foundation backed education technology (ed tech) interoperability solution, bears an important lesson for education policymakers who grapple with balancing big data innovation and privacy and security concerns. ${ }^{85}$ Disruptive education technologies promising innovative value propositions for schools, parents and students cannot rely on formulaic compliance mechanisms and legal minutiae to allay public angst around data use. ${ }^{86} \mathrm{In}$ fact, legal technicalities, including longwinded privacy notices and dense terms of contract, may send out the wrong message. If vendors are regarded as being motivated to misuse or sell student information rather than to serve their users with the highest quality educational services, there is little hope for ed tech. Indeed, even with the raging privacy backlash, there was no evidence that inBloom committed any privacy or security violation at all - no data breach, no monetization of student information, no unexpected repurposing of data. Yet this did not stop ed tech critics and parent groups from accusing it of malfeasance ranging from selling children's information to downright identity theft. ${ }^{87}$

To embrace ed tech innovation, schools and vendors must engender an environment of trust and a culture of ethical data use. When stakeholders, including teachers, parents and students, are presented with the value proposition and understand the philosophy around institutions' data management, the flames of dissent will greatly subside. This is why the escalating drumbeat of calls for legislative reform, including more than 100 education privacy bills pending in state legislatures, ${ }^{88}$ as well as for tighter contractual obligations, ${ }^{89}$ while important, will not solve the problem. To be sure, schools and vendors must comply with laws and existing privacy regulation, but as we explain in $A$ Theory of Creepy, ${ }^{90}$ social norms are rarely established by regulatory fiat, and laws that fail to reflect techno-social reality do not fare well in the real world. We write that "Part of the problem lies in the incongruity between the availability of digital information about individuals and the opacity of the purposes, uses, and intentions of those accessing such information." 91 To reduce parents' anxiety and teachers' dissent to ed tech solutions, schools must first figure out and articulate their data use philosophy and convey it to relevant stakeholders. As many businesses have learned firsthand, in an area as fraught with social sensitivities and frequent misperceptions as privacy, legal compliance does not make up for a lack of coherent policy vision.

\section{Changes in education}

Ed tech is revolutionizing learning environments from $\mathrm{K}-12$ to higher education, from apps for toddlers to massive online open courses (MOOCs). ${ }^{92}$ Online educational resources and interactive tools experience hockey stick growth; new social media platforms emerge, connecting teachers, parents and students and providing tools for engagement, learning and class administration; and cloud platforms provide opportunities for cost

\footnotetext{
${ }^{85}$ Benjamin Herold, inBloom to Shut Down Amid Growing Data-Privacy Concerns, Educ. WK. (Apr. 21, 2014), http://blogs.edweek.org/edweek/DigitalEducation/2014/04/inbloom to shut down amid growing data privacy concerns.html?cmp=SOC-SHR-TW.

${ }^{86}$ Omer Tene, InBloom Wilts Amid Privacy Backlash, Privacy Perspectives, April 22, 2014, available at https://www.privacyassociation.org/privacy perspectives/post/inbloom wilts amid_privacy backlash.

${ }^{87}$ See Diane Ravitch, Is inBloom Engaged in Identity Theft?, DIANE RAVITCH'S BLOG (Apr. 7, 2013), http://dianeravitch.net/2013/04/07/isinbloom-engaged-in-identity-theft/.

${ }^{88}$ Andrew Ujifusa, State Lawmakers Ramp Up Attention to Data Privacy, EDUc. WK. (April 15, 2014), http://www.edweek.org/ew/articles/2014/04/16/28data.h33.html.

89 Joel Reidenberg et al., Privacy and Cloud Computing in Public Schools, Fordham Ctr. L. \& Info. Pol'y (Dec. 2013) [hereinafter CLIP report], available at http://ir.lawnet.fordham.edu/cgi/viewcontent.cgi?article=1001\&context=clip.

90 Omer Tene \& Jules Polonetsky, A Theory of Creepy: Technology, Privacy and Shifting Social Norms, 16 YALE J. L. \& TECH. 59 (2013).

${ }^{91} \mathrm{Id}$, at 71.

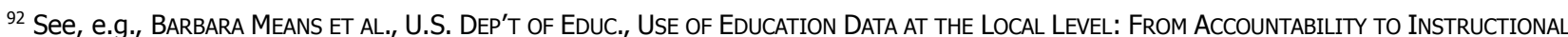
IMPROVEMENT (2010), available at http://www2.ed.gov/rschstat/eval/tech/use-of-education-data/use-of-education-data.pdf; Lev Gonick, The Year Ahead in IT, 2013, INSIDE Higher ED (Jan. 3, 2013), http://www.insidehighered.com/views/2013/01/03/predictions-abouthigher-ed-technology-2013-essay; Roger Riddell, What Trends Are Shaping Ed Tech in 2014, EDUCATION DRIVE (Feb. 6, 2014), http://www.educationdive.com/news/what-trends-are-shaping-ed-tech-in-2014/223048/.
} 
efficient and secure data storage, interoperability and collaboration. Student performance data is driving nextgeneration models of learning and measurements for teacher effectiveness; and connected learning is fast becoming a path for access and academic achievement. Information and data are flowing within schools and beyond, enabling a new learning environment and providing much needed analytics to understand and improve the way teachers teach and students learn.

\section{Ed tech}

According to Secretary of Education Arne Duncan, student data holds the promise of providing educators with a roadmap for reform: "[Data] tells us where we are, where we need to go, and who is most at risk. "93 The Department of Education has identified using student data systems to help students and improve education as a top national priority. ${ }^{94}$ Data driven ed tech innovation provides education institutions with robust tools to improve teaching and instructional methods; diagnose students' strengths and weaknesses and adjust materials and approaches for individual learners; and identify at-risk students so teachers and counsellors can intervene. At the same time, critics fear the emergence of novel risks of privacy infringements, narrowcasting and discrimination, fuelling the stratification of society by channelling "winners" to a "Harvard track" and "losers" to a "bluer collar" track; and overly limiting the right to fail, struggle and learn through experimentation.

Ed tech comprises an ever-expanding group of technologies, product suites, apps, cloud platforms and social networks, which attempt to augment, and in some cases replace, traditional education administration and content delivery systems. They include learning management systems like Blackboard and Moodle, which provide an infrastructure for teacher management and distribution of course content; digital content and open educational resources, starting with Wikipedia entries and culminating with the full fledged curricula of MOOCs; specialized social media platforms, such as Edmodo, which enable interaction between teachers, parents and students as well as content distribution and management of class assignments; and adaptive learning optimization platforms, such as Knewton, which effectively "read" students even as students read and work through problems, tailoring individualized content and assignments to student capabilities and allowing for continual assessment of students' skills, shortcomings and strengths through dynamic, interactive dashboards.

\section{inBloom}

InBloom was designed to improve and standardize the connection among widely varied education applications. It allowed schools to centrally store student data in an encrypted, cloud-based system that educators could access to collect data from a variety of third-party vendors. In its mission statement, it promised to "solve a common technology issue facing school districts today: the inability of electronic instructional tools used in classrooms to work in coordination with (or 'talk to') one another." Financed by a $\$ 100$ million grant from the Gates Foundation and Carnegie Corporation, it engaged school districts in seven states, with Louisiana and New York later joining on a state-wide basis. By 2014, it managed information on millions of children around the country in K-12 schools. ${ }^{95}$

Unfortunately for inBloom, it became a lightning rod for education reform opponents who portrayed it as a cavalier experiment in children's data. ${ }^{96}$ It raised difficult questions about the reliance of the education sector on commercial vendors and deployment of big data techniques in an area fraught with concerns about children's

93 Arne Duncan, Robust Data Gives Us The Roadmap to Reform, Fourth Annual IES Research Conference, June 8, 2009, available at http://www2.ed.gov/news/speeches/2009/06/06082009.html.

94 United States Department of Education, Use of Education Data at the Local Level: From Accountability to Instructional Improvement, 2010, available at http://www2.ed.gov/rschstat/eval/tech/use-of-education-data/use-of-education-data.pdf.

${ }_{95}$ Natasha Singer, Deciding Who Sees Students' Data, N.Y. TIMES (Oct. 5, 2013), http://www.nytimes.com/2013/10/06/business/decidingwho-sees-students-data.html.

${ }^{96}$ Leonie Haimson, It's Apparently the End of the Line for inBloom, but Not Our Fight to Protect Student Privacy, N.Y.C. PUB. SCHOOL PARENTS (Apr. 2, 2014), http://nycpublicschoolparents.blogspot.com/2014/04/parent-power-wins-ny-severs-its.html. 
futures. It brought to the fore weighty policy choices, which required sophisticated technology leadership and policy articulation. This eventually led states to backpedal from signed transactions, culminating in the initiative's premature implosion. ${ }^{97}$

InBloom's demise demonstrates the risks inherent in the divisive policy debates raging around ed tech. On the one hand, education reformers seek to revolutionize schools by introducing standardized testing and tools for performance measurement and analysis. They argue that technology and data empower teachers to improve their skills and provide critical feedback about what is or is not working for individual students, classes and schools. On the other hand, education traditionalists claim that education reform should be focused on increasing teachers' pay, hiring subject matter experts and keeping class size small. ${ }^{98}$ They warn that ed tech leans in the opposite direction, repositioning teachers as factory line workers who are scored based on student throughput and substituting a preoccupation with test preparation for a culture of learning. ${ }^{99}$ The debate continues with reformers claiming that, to the contrary, under the current system, students are treated like widgets while ed tech enables personalization and individual attention to students' unique needs.

The conflation of concerns around privacy and big data with debates about the structure of public education has been counterproductive. In order to facilitate a level-headed discussion of the policy issues arising from the introduction of ed tech into schools, privacy and data security problems should be disentangled from broader education policy debates.

\section{Privacy concerns}

Schools have always relied on broad scale collection and use of students' data, aggregating information about students' attendance, grades, disciplinary records, medical conditions, socio economic backgrounds and more. ${ }^{100}$ But in reality, education has long been data rich and information poor, collecting information but storing it in formats and silos that made it inaccessible and inactionable. Now, ed tech innovations are making it possible to analyse student data to inform individual and systemic decisions, affecting the delivery of curricula, allocation of resources and accountability. As recognized by the Obama Administration's May 2014 report on data and privacy, "Students and their families need robust protection against current and emerging harms, but they also deserve access to the learning advancements enabled by technology that promise to empower all students to reach their full potential."101 This part sets forth the main privacy concerns for ed tech reformers.

\section{Third party vendors}

Ed tech critics condemn schools for sharing student data with commercial technology vendors. ${ }^{102}$ They raise a plethora of concerns ranging from inadequate security controls to monetization of children's information. According to a recent report by the Fordham School of Law's Centre on Law and Information Policy, school vendor contracts with cloud service providers frequently fail to impose data governance and security obligations required under the law. ${ }^{103}$

\footnotetext{
${ }_{97}$ Natasha Singer, InBloom Student Data Repository to Close, N.Y. TIMES (Apr. 21, 2014), http://bits.blogs.nytimes.com/2014/04/21/inbloom-student-data-repository-to-close/?hpw\&rref=technology.

${ }^{98}$ See Leonie Haimson, Why Class Size Matters, Parents Across Am., http://parentsacrossamerica.org/what-we-believe-2/why-class-sizematters/ (last visited May 5, 2014).

99 See Diane Whitmore SchanzenBaCh, NAT'L Educ. Policy CtR., Does Class Size MatTer?,(Feb. 2014), http://www.classsizematters.org/wpcontent/uploads/2014/02/207632499-Pb-Class-Size.pdf.

100 Susan P. Stuart, Lex-Praxis of Education Informational Privacy for Public Schoolchildren, 84 Neb. L. Rev. 1158, 1159 (2006).

101 "Big Data: Seizing Opportunities, Preserving Values" Executive Office of the President, p.64 (May 2014). http://www.whitehouse.gov/sites/default/files/docs/big data privacy report may 1 2014.pdf.

102 CLIP Report, supra note 89.

${ }^{103} \mathrm{Id}$
} 
To be sure, when working with technology vendors, schools cannot be allowed to abdicate their legal responsibilities toward students' privacy. ${ }^{104}$ Yet, simply amending vendor contracts and complying with technical data management obligations will do little to advance an environment of trust. Instead, schools must better communicate their data philosophy, why they seek to engage various vendors and what are their information-driven goals. Effective communication cannot be achieved through traditional privacy notices. As the President's Council of Advisors on Science and Technology recently remarked, "Only in some fantasy world do users actually read these notices and understand their implications before clicking to indicate their consent." 105 Rather, data policies must feature front and centre on school board agendas, debated in town hall meetings and discussed in open fora among administrators, principals, teachers and parents.

\section{Commercialization}

The use of student data for commercial activities is clearly of concern to parents. ${ }^{106}$ Yet opinions differ with respect to what constitutes legitimate commercial activity in schools. ${ }^{107}$ Some anti-marketing voices oppose exposing children to any commercial content, regardless of whether their personal data is used. They would restrict placing billboards or branding merchandise in school cafeterias or playing fields or serving generalized, non-targeted ads on an online school blog. Others are specifically alarmed by commercial uses of children's data, regardless of whether those children are presented with ads. They oppose vendors' use of student information to enhance and improve existing products and services, including education related offerings that could benefit those students' schools.

Many forms of commercialization exist between these two categories. Most observers agree that targeting students with personalized ads or selling their information to third parties is inappropriate. Yet many schools have a decades-long history providing data to yearbook publishers, school photographers, class ring and spiritwear vendors. And what about marketing new education products or services to students based on their previous performance, for example, recommending an advanced grammar app after a student completes the beginner app? Or leveraging lessons from students' interaction with a product or service app in order to improve another non-education related product or service offered by the same vendor? Clearly, schools acting in concert with relevant stakeholders should debate these questions transparently to form a coherent approach.

More generally, critics fear the growing role of business in education. Warning that technology could turn classrooms into showrooms, they point out that companies that once sold textbooks and testing have now become market leaders in an "industry of learning." Indeed, for-profit MOOCs like Coursera and Udacity have become education institutions in their own right, threatening the traditional business model of non-profit colleges and universities. ${ }^{108}$ Increasingly, the debate is focused on whether technology has begun to usurp, or at least transform, roles traditionally fulfilled by teachers and schools.

\footnotetext{
${ }^{104}$ Daniel Solove, Big Data and Our Children's Future: On Reforming FERPA, LINKEDIN, https://www.linkedin.com/today/post/article/20140507051528-2259773-big-data-and-our-children-s-future-on-reforming-ferpa

105 President's Council of Advisors on SCi. And TeCH., EXec. OfFice of the President, Report to the President: Big Data And PRIVACy: A TECHNOLOGICAL PERSPECTIVE Xi (May 2014), http://www.whitehouse.gov/sites/default/files/microsites/ostp/PCAST/pcast big data and privacy - may 2014.pdf.
}

106 Benjamin Herold, Americans Worried, Uninformed About Student Data Privacy, Survey Finds, EdWeek (Jan. 22, 2014), http://blogs.edweek.org/edweek/DigitalEducation/2014/01/american worried uninformed student data privacy.html.

107 See Alex Molnar et Al., Nat'l Educ. Policy Ctr., Schoolhouse Commercialism Leaves Policymakers Behind - The Sixteenth Annual RePORT ON SCHOOLHOUSE COMMERCIALIZING TRENDS: 2012-2013, available at http://nepc.colorado.edu/files/trends-2013.pdf.

108 Massive Open Online Forces, THE ECONOMIST (Feb. 6, 2014), http://www.economist.com/news/finance-and-economics/21595901-riseonline-instruction-will-upend-economics-higher-education-massive. 


\section{Big data concerns}

The use of data analysis for measurement and optimization inevitably unmasks truths that may be uncomfortable to some, but invaluable for others. ${ }^{109}$ Prestigious schools may be exposed as underachievers, university acceptance criteria as systematically biased, and children across their nation as underperforming their peers in other parts of the world. ${ }^{110}$

Big data analysis stokes fear of discrimination and social stratification. Data analytics can render discrimination difficult to weed out, by hiding discriminatory intent behind multiple layers of masks and proxies. ${ }^{111}$ As the White House recently observed in its Big Data Report, "algorithmic decisions raise the specter of 'redlining' in the digital economy - the potential to discriminate against the most vulnerable classes of our society under the guise of neutral algorithms."112

But big data not only creates discrimination; it can also help discover it enabling legal mechanisms to react. ${ }^{113}$ The White House Report notes, "The same big data technologies that enable discrimination can also help groups enforce their rights. Applying correlative and data mining capabilities can identify and empirically confirm instances of discrimination and characterize the harms they caused."114

Enhanced personalization could create echo chambers and filter bubbles that are anathema to education's horizon broadening role. ${ }^{115}$ Yet, the vision of adaptive learning pioneered by companies like Knewton promises to help individual students maximize their ability and guarantees disadvantaged learners tailor-made solutions to help them catch up. Ed tech enthusiasts argue that the current status quo, which treats all students alike, is flattening out the education system weighing down on high achievers and leaving struggling students behind.

\section{A solution toolkit}

Addressing ed tech policy concerns requires initial separation of disparate policy issues involving education policy, privacy and big data. Ed tech has long suffered from a conflation of concerns around children's privacy with decisions that impact resource allocation among entrenched interest groups. Ed tech threatens to upend the balance between national and local control over education, between education experts and teacher unions, school administrators and parent groups. It stokes parents' fears of monetization and commodification of students' data, in ways that could impact their children's long-term prospects for education and employment.

Some of the privacy problems can be dealt with under the existing regulatory frameworks. Clearly, vendor contracts should be tightened to enhance school control over the purposes of data use; data security must meet standards appropriate to the sensitivity of the data collected; and commercial uses of data outside of the education space must be restricted to comply with the law. Educational systems and ed tech vendors should put in place data governance mechanisms, including the appointment of a chief privacy officer, setting forth

\footnotetext{
${ }^{109}$ Richard J. Peltz, From the Ivory Tower to the Glass House: Access to "De-Identified" Public University Admission Records to Study Affirmative Action, 25 HARV. BLACKLETTER L.J. 181 (2009).

110 See, e.g., Tim Post, Bill Targets Underperforming Minn. Charter Schools, MPR NEWs (Feb. 10, 2014), http://www.mprnews.org/story/2014/02/09/proposed-bill-would-subject-charter-schools-to-more-scrutiny.

${ }^{111}$ See Omer Tene \& Jules Polonetsky, Judged by the Tin Man: Empowering Individuals in an Age of Big Data, 11 J. TELECOM. \& HIGH TECH. L. 351 (2013).

112 EXEC. OFFICE OF THE PRESIDENT, supra note 101 at 46.

${ }^{113}$ Liana Christin Landivar, Disparities in STEM Employment by Sex, Race and Hispanic Origin, Am. COMmUNITY SURVEY REPORTS (Sept. 2013), http://www.census.gov/prod/2013pubs/acs-24.pdf; Donna K. Ginther et al., Race, Ethnicity, and NIH Research Awards, 333 ScI. 1015 (2011), available at http://www.sciencemag.org/content/333/6045/1015.full.

${ }^{114}$ EXEC. OfFICE OF THE PRESIDENT, supra note 101.

115 Joseph TURow, The Daily You: How the New Advertising Industry Is Defining Your Identity AND Your Worth (2011). For similar arguments, see Eli PARISER, THe Filter Bubble: What THE INTERnet Is Hiding From You (2011).
} 
data management policies, and introducing periodic assessments and audits to verify compliance. However, these measures alone will not suffice to set an environment where parents, teachers and policymakers can rationally assess the merits of new technologies and uses of data.

\section{Transparency and Trust}

Trust is key for the adoption of innovative technology in the education space. Ed tech solutions cannot succeed if schools, teachers and parents assume that technology vendors are motivated by preying on student information. Schools and vendors will not engender trust simply by tweaking contracting practices or complying with the legal technicalities. Teachers, parents and students cannot be expected to read, much less understand, vendor contracts; and they will likely not be satisfied by an additional contract clause. Rather, trust will be built by enhancing transparency into data practices to both demonstrate to the various stakeholders the benefits and promise of data use and assuage the rampant fears raised by critics..

Schools must actively engage parents and teachers to debate and achieve consensus for a data use philosophy and to advocate their approach to harnessing the power of data. To do so, they must first articulate such policies themselves. As businesses have learned time and again, a proactive approach to communicating with stakeholders about how data is being used is what distinguishes between riding the wave of data innovation and being crushed by it. For many schools, communication with parents about data practices is limited to formal notices and terms of use. More should be done to bring parents along.

\section{Transparency Through Featurization}

In order to understand and experience the value of ed tech, parents must have meaningful rights to access their children's data in a clear and usable format. This, in turn, will unleash a wave of innovation for parent, student and teacher applications based on access to data, a process we refer to as data "featurization."116 Featurization will allow parents to access their children's information through dashboards and interact with it in meaningful ways. Currently the only insight parents have to their child's school life is a quarterly report card, which leaves too much untold. With meaningful access to data, parents would be able to see the inner components of each grade, understand their child's strengths and weaknesses, and engage in meaningful ways with teachers and schools. One existing idea for featurizing data is that of a "digital backpack," allowing students and parents to download data in a usable format to a portable digital vault. Such as backpack would follow students as they transition between grades and schools. It would include traditional transcript information, as well as additional data concerning students' assignments, attendance, behaviour patterns and proficiency scores, providing a more holistic picture their skills and achievements and helping teachers better support their individualized needs. Other solutions include interactive data dashboards and APIs through which parents and students can actively engage data, enabling learning opportunities beyond the classroom and opportunities for further enrichment and growth.

\section{Seeking Ethical Outcomes}

In a world of big data, transparency must extend beyond simple access to raw information to provide insight into the inner working of algorithmic decision-making processes. To alleviate concerns about discreet discrimination, policymakers and parents must understand how and to what effect student data is being used. Hence, ed tech should be accompanied by a push to disclose organizations' decisional criteria, i.e., not necessarily the algorithms they use but rather the factors they consider in their decision. ${ }^{117}$ One proposal to help defuse some of the ethical dilemmas surrounding algorithmic decision-making calls for the establishment of privacy ethics boards, modelled after the human subject review boards (IRBs) that operate in academic research institutions.

\footnotetext{
${ }^{116}$ Omer Tene \& Jules Polonetsky, Big Data for All: Privacy and User Control in the Age of Analytics, 11 Nw J. Tech \& IP 239,268 (2013).

${ }^{117}$ Id. at 270-72; also see Jules Polonetsky \& Omer Tene, Privacy and Big Data: Making Ends Meet, 66 Stan. L. Rev. Online 25 (2013).
} 
Ryan Calo explains, "Today, any academic researcher who would conduct experiments involving people is obligated to comply with robust ethical principles and guidelines for the protection of human subjects." 118 He posits that by formalizing the review of new initiatives involving consumer data, policy managers could manage and head off regulatory risk, and more importantly, add a measure of legitimacy to the study of consumer activity. ${ }^{119}$ A similar model could be implemented in states and school districts, to help vet ed tech projects and enhance the transparency and accountability of automated decisions affecting students and teachers. Such scrutiny would also help address the concerns of civil rights groups that worry that big data advances could exacerbate bias or create new forms of discrimination.

By advancing transparency and enabling platforms for critical review, reformers can shape a system that uses ed tech to provide students the best learning experiences that the future allows.

\section{References}

Calo, Ryan: Consumer Subject Review Boards: A Thought Experiment, 66 Stanford Law Review Online 97 (2013), http://www.stanfordlawreview.org/online/privacy-and-big-data/consumer-subject-review-boards

Duncan, Arne: Robust Data Gives Us The Roadmap to Reform, Fourth Annual IES Research Conference, June 8, 2009, http://www2.ed.gov/news/speeches/2009/06/06082009.html

Executive Office of the President: Big Data: Seizing Opportunities, Preserving Values, May 2014, p. 64, http://www. whitehouse.gov/sites/default/files/docs/big data privacy report may 1 2014.pdf

Ginther, Donna K.; Schaffer, Walter T.; Schnell, Joshua; Masimore, Beth; Liu, Faye; Haak, Laurel L.; Kington, Richard: Race, Ethnicity, and NIH Research Awards, 333 Science 1015, 2011, http://www.sciencemag.org/content/333/6045/1015. full

Gonick, Lev: The Year Ahead in IT, 2013, Inside Higher Ed, Jan. 3, 2013, http://www.insidehighered.com/views/2013/01/03/predictions-about-higher-ed-technology-2013-essay

Haimson, Leonie: It's Apparently the End of the Line for inBloom, but Not Our Fight to Protect Student Privacy, NYC Public School Parents, April 2, 2014, http://nycpublicschoolparents.blogspot.com/2014/04/parent-power-wins-ny-severs-its. html

Haimson, Leonie: Why Class Size Matters, Parents Across America, http://parentsacrossamerica.org/what-webelieve-2/why-class-size-matters/

Herold, Benjamin: inBloom to Shut Down Amid Growing Data-Privacy Concerns, Education Week, April 7, 2014, http://blogs.edweek.org/edweek/DigitalEducation/2014/04/inbloom to shut down amid growing data privacy concerns.html?cmp=SOC-SHR-TW

Herold, Benjamin: Americans Worried, Uninformed About Student Data Privacy, Survey Finds, Education Week, Jan. 22, 2014, http://blogs.edweek.org/edweek/DigitalEducation/2014/01/american worried uninformed student data privacy.html

Landivar, Liana Christin: Disparities in STEM Employment by Sex, Race and Hispanic Origin, American Community Survey Reports, Sept. 2013, http://www.census.gov/prod/2013pubs/acs-24.pdf

Molnar, Alex; Boninger, Faith; Fogarty, Joseph: Schoolhouse Commercialism Leaves Policymakers Behind, The Sixteenth Annual Report on Schoolhouse Commercializing Trends: 2012-2013, National Education Policy Center, Mar. 2014, http://nepc.colorado.edu/files/trends-2013.pdf

Pariser, Eli: The Filter Bubble: What the Internet Is Hiding from You. New York, Penguin Press 2011

Peltz, Richard J.: From the Ivory Tower to the Glass House: Access to "De-Identified" Public University Admission Records to Study Affirmative Action, 25 Harvard Blackletter Law Journal 181 (2009)

\footnotetext{
${ }^{118}$ Ryan Calo, Consumer Subject Review Boards: A Thought Experiment, 66 STAN. L. REv. ONLINE 97 (2013), http://www.stanfordlawreview.org/online/privacy-and-big-data/consumer-subject-review-boards.

${ }^{119} \mathrm{Id}$.
} 
Polonetsky, Jules; Tene, Omer: Privacy and Big Data: Making Ends Meet, 66 Stanford Law Review Online 25 (2013)

Post, Tim: Bill Targets Underperforming Minn. Charter Schools, MPR News, Feb. 10, 2014, http://www.mprnews.org/story/2014/02/09/proposed-bill-would-subject-charter-schools-to-more-scrutiny

President's Council of Advisors on Science and Technology, Executive Office of the President: Report to the President: Big Data and Privacy: A Technological Perspective, May 2014, p. xi, http://www.whitehouse.gov/sites/default/files/microsites/ostp/PCAST/pcast big data and privacy may 2014.pdf

Ravitch, Diane: Is inBloom Engaged in Identity Theft?, Diane Ravitch's Blog, April 7, 2013, http://dianeravitch.net/2013/04/07/is-inbloom-engaged-in-identity-theft/

Reidenberg, Joel; Russell, Cameron N.; Kovnot, Jordan; Norton, Thomas B.; Cloutier, Ryan: Privacy and Cloud Computing in Public Schools, Fordham Center for Law and Information Policy, Dec. 2013, http://ir.lawnet.fordham.edu/cgi/viewcontent.cgi?article=1001\&context=clip

Riddell, Roger: What Trends Are Shaping Ed Tech in 2014, Education Drive, Feb. 6, 2014, http://www.educationdive.com/news/what-trends-are-shaping-ed-tech-in-2014/223048/

Singer, Natasha: Deciding Who Sees Students' Data, New York Times, Oct. 5, 2013, http://www.nytimes.com/2013/10/06/business/deciding-who-sees-students-data. htm/

Singer, Natasha: InBloom Student Data Repository to Close, New York Times, April 21, 2014, http://bits.blogs.nytimes.com/2014/04/21/inbloom-student-data-repository-to-close/?hpw\&rref=technology

Solove, Daniel: Big Data and Our Children's Future: On Reforming FERPA, LinkedIn, May 7, 2014, https://www.linkedin.com/today/post/article/20140507051528-2259773-big-data-and-our-children-s-future-on-reforming-ferpa

Stuart, Susan P.: Lex-Praxis of Education Informational Privacy for Public Schoolchildren, 84 Nebraska Law Review 1158, 1159 (2006)

Tene, Omer: InBloom Wilts Amid Privacy Backlash, Privacy Perspectives, April 22, 2014, https://www.privacyassociation.org/privacy perspectives/post/inbloom wilts amid privacy backlash

Tene, Omer; Polonetsky, Jules: A Theory of Creepy: Technology, Privacy and Shifting Social Norms, 16 Yale Journal of Law and Technology 59 (2013)

Tene, Omer; Polonetsky, Jules: Big Data for All: Privacy and User Control in the Age of Analytics, 11 Northwestern Journal of Technology and Intellectual Property 239, 268 (2013)

Tene, Omer; Polonetsky, Jules: Judged by the Tin Man: Empowering Individuals in an Age of Big Data, 11 Journal of Telecommunications and High Technology LaW 351 (2013)

The Economist, Massive Open Online Forces, Feb. 6, 2014, http://www.economist.com/news/finance-andeconomics/21595901-rise-online-instruction-will-upend-economics-higher-education-massive

Turow, Joseph: The Daily You: How the New Advertising Industry Is Defining Your Identity and Your Worth. New Haven/London, Yale University Press 2011

Ujifusa, Andrew: State Lawmakers Ramp Up Attention to Data Privacy, Education Week, April 15, 2014, http://www.edweek.org/ew/articles/2014/04/16/28data.h33.htm/

U.S. Department of Education, Use of Education Data at the Local Level: From Accountability to Instructional Improvement (2010), http://www2.ed.gov/rschstat/eval/tech/use-of-education-data/use-of-educationdata.pdf

Whitmore-Schanzenbach, Diane: Does Class Size Matter?, National Education Policy Center, Feb. 2014, http://www.classsizematters.org/wp-content/uploads/2014/02/207632499-Pb-Class-Size.pdf 